\title{
PMS1 Gene
}

National Cancer Institute

\section{Source}

National Cancer Institute. PMS1 Gene. NCI Thesaurus. Code C18590.

This gene is involved in mismatch repair and mutations in the gene result in hereditary non-polyposis colon cancer 3 . 